\title{
Optimisation of enzyme-assisted extraction of ferulic acid from sweet corn cob by response surface methodology
}

Article

Accepted Version

Lau, T., Harbourne, N. and Oruña-Concha, M. J. (2020) Optimisation of enzyme-assisted extraction of ferulic acid from sweet corn cob by response surface methodology. Journal of the science of food and agriculture, 100 (4). pp. 1479-1485. ISSN 1097-0010 doi: https://doi.org/10.1002/jsfa.10155 Available at https://centaur.reading.ac.uk/87760/

It is advisable to refer to the publisher's version if you intend to cite from the work. See Guidance on citing.

To link to this article DOI: http://dx.doi.org/10.1002/jsfa.10155

Publisher: Wiley

All outputs in CentAUR are protected by Intellectual Property Rights law, including copyright law. Copyright and IPR is retained by the creators or other copyright holders. Terms and conditions for use of this material are defined in the End User Agreement.

www.reading.ac.uk/centaur 
Central Archive at the University of Reading

Reading's research outputs online 


\title{
Optimisation of enzyme assisted extraction of ferulic acid from sweet corn cob by
} response surface methodology

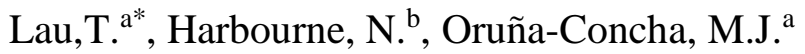 \\ ${ }^{a}$ Department of Food and Nutritional Sciences, University of Reading, UK. \\ ${ }^{\mathrm{b}}$ UCD Institute of Food and Health, School of Agricultural and Food Science, \\ University College Dublin, Belfield, Dublin. \\ *corresponding author. Present address: Department of Food and Nutritional Sciences, \\ Whiteknights, Reading, Berkshire, RG6 6AP, Reading, United Kingdom \\ Email address: t.lau2@reading.ac.uk
}

This article has been accepted for publication and undergone full peer review but has not been through the copyediting, typesetting, pagination and proofreading process which may lead to differences between this version and the Version of Record. Please cite this article as doi: $10.1002 /$ jsfa. 10155 


\begin{abstract}
Sweet corn cob (SCC), an agricultural by-product of the corn processing industry, contains more than $80 \%$ insoluble-bound ferulic acid (FA). Extraction of these bound phenolics can be achieved through chemical or enzymatic hydrolysis, however the shift towards greener chemistry has raised awareness towards the use of enzymatic hydrolysis. In the present study, the ability of ferulic acid esterase (FAE) and xylanase (XY) to catalyse the hydrolysis of FA from SCC was investigated. Response surface methodology (RSM) based on a five-level, fourfactor central composite rotatable design (CCRD) was used to establish the optimum conditions for enzymatic hydrolysis of FA from SCC. SCC was treated with the combination of FAE and $\mathrm{XY}$ at various concentrations (FAE: 0.00 to $0.04 \mathrm{U} / \mathrm{g}$; XY: 0.00 to $18093.5 \mathrm{U} / \mathrm{g}$ ), temperatures (45 to $65^{\circ} \mathrm{C}$ ) and $\mathrm{pH}$ (pH 4.5 to 6.5). RESULTS: The optimum extraction conditions predicted by the model were: FAE concentration of $0.02 \mathrm{U} / \mathrm{g}$, XY concentration of $3475.3 \mathrm{U} / \mathrm{g}$, extraction $\mathrm{pH}$ of 4.5 and extraction temperature of $45^{\circ} \mathrm{C}$. CONCLUSION: Under these conditions, the experimental yield of FA was $1.69 \pm 0.02 \mathrm{~g} \mathrm{~kg}^{-1}$ of SCC, which is in agreement with the value predicted by the model.
\end{abstract}

\title{
Keywords
}

Sweet corn cob; response surface methodology; ferulic acid; ferulic acid esterase; xylanase.

\section{Highlight}

- $\quad$ RSM was used to optimise the extraction of ferulic acid from SCC.

- Optimum extraction conditions were FAE concentration at $0.02 \mathrm{U} / \mathrm{g}, \mathrm{XY}$ concentration at $3475.4 \mathrm{U} / \mathrm{g}$, $\mathrm{pH} 4.5$ and $45^{\circ} \mathrm{C}$. 
- The yield of ferulic acid was $1.69 \pm 0.02 \mathrm{~g} \mathrm{~kg}^{-1}$ of SCC at optimum extraction conditions.

\subsection{INTRODUCTION}

The annual world production of corn is about 520 teragram with most of the corn being used for animal feed or human consumption (64 and 19\% of global production, respectively) $(\underline{1}, \underline{2})$. Sweet corn cobs (SCC) are an agricultural by-product of the corn-processing industry. Zheng, Choo (3) reported that the average yield of corn cob is about $14 \%$ of grain yield, which accounts for up to $16 \%$ of the total corn stover in a field. Utilization of corncob as animal beddings (4), biological substrate for the production of furfural (ㅁ), carbon adsorbents (ㅁ) and forage protein ( $\underline{7}$ ) have been widely studied. In addition, research on corn cob as a source of ferulic acid (FA) has notably increased in recent years (ㅁ). FA has been reported to exhibits a wide range of therapeutic effects against various diseases including diabetes, cancer, neurodegenerative and cardiovascular diseases (모). In addition, FA can also prevent oxidation and has been approved to be used as food additives in beverages, food and cosmetic in Japan (10). Based on previous findings using alkaline hydrolysis, $97 \%$ of FA in corn cob was present in insoluble bound form. The insoluble bound FA is covalently bound to the polysaccharide components of plants through ester linkages and these crosslinks significantly limit the degradation of cell wall by rumen microorganism, thus limiting the digestibility by ruminants (11).

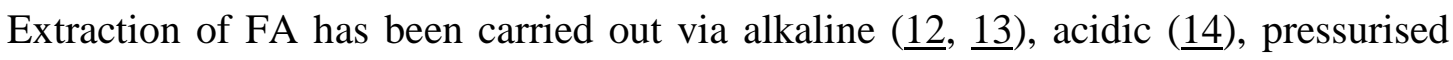

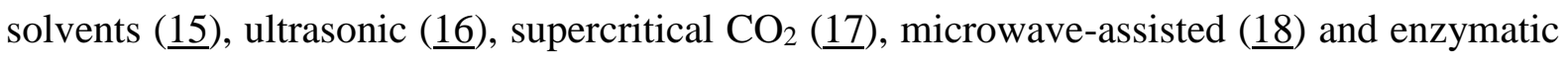
(19) $)$ extraction. Commonly, the release of FA from SCC has been carried out using alkali 
hydrolysis $(\underline{13}, \underline{20}, \underline{21})$. The yield of FA from SCC was reported to be $3.06 \mathrm{~g} \mathrm{~kg}^{-1}(\underline{22}), 7.65 \mathrm{~g}$ $\mathrm{kg}^{-1}(\underline{23})$ and $1171 \mathrm{mg} \mathrm{L}^{-1}(\underline{20})$, respectively. However, this conventional method of hydrolysis has several disadvantages including usage of large amount of solvent and subsequent solvent disposal problems (24), leading to an increase in environmental pollution. In this context, enzymatic hydrolysis has drawn great interest due to its lower environmental impact as the use of chemicals is negligible and requires low energy (트). Recently, Pérez-Rodríguez, Torrado Agrasar (26) investigated the utilization of high hydrostatic pressure along with feruloly esterase on the release of FA from corn cob. Ferulic acid esterase (FAE) was reported to break the ester linkage between FA and the attached sugar, thus releasing the FA from the complex cell wall (1ㅡ). However, a specific cell wall degrading enzyme such as xylanase could be used to further improve the extraction by solubilizing part of the cell wall structure and forming low molecular weight ferulolyted compounds, to allow FAE to act on these low molecular weight ferulolyted compounds releasing the FA (27).

However, the main drawback of using enzymatic hydrolysis is the low hydrolysis rate as compared to chemical hydrolysis. To overcome this, several physicochemical factors such as incubation temperature, incubation time, enzyme concentration and $\mathrm{pH}$ need to be considered prior to enzymatic hydrolysis (28). The conventional optimization involves changing one independent variable at a time while keeping the rest of the factors constant. However, this conventional experimental design does not include interaction among the variables and therefore is often incapable of detecting the optimum conditions (로). In order to overcome this problem, response surface methodology (RSM) can be used to carry out optimization studies ( $\underline{30})$. RSM is less laborious and time-consuming than conventional 
optimisation methods as it reduces the number of experimental trials needed to evaluate the effect of multiple parameters and their interaction (28). Previously, RSM has been used to optimize the extraction of FA from various agricultural waste including paddy straw (2) , rice bran, maize bran, wheat straw, wheat bran, sugar cane bagasse, orange peels, pomegranate peels and pineapple peels (푸).

Previous studies on the alkali hydrolysis of SCC showed that it contains $3.06 \mathrm{~g} \mathrm{~kg}^{-1}$ of total FA (13). Hence, this research aimed to investigate the effect of extraction parameters (enzyme concentration of FAE and XY, $\mathrm{pH}$, and temperature) on the yield of FA from sweet corn cob. RSM optimisation by central composite rotatable design (CCRD) was used for model fitting and to predict the optimum condition for the extraction FA from sweet corn cob.

\subsection{EXPERIMENTAL}

\subsection{Materials}

Sweet corn cob (SCC) used in this study was harvested in Senegal in December 2015 and was kindly provided by Barfoots of Botley Company Ltd (West Sussex, United Kingdom). Ferulic acid esterase (FAE) by Clostridium thermocellum and endo-1,4- $\beta$-xylanase (XY) by Trichoderma viride were purchased from Prozomix Limited (Northumberland, United Kingdom) and Megazyme International Ireland Limited (Bray, Ireland). All other chemicals used in this experiment were of analytical grade.

\subsection{Sample preparation}

The corn kernels were removed manually from the cob and discarded. The sweet corn cobs were then chopped into $5 \mathrm{~cm}$ pieces in length, and frozen in a blast freezer $\left(-18^{\circ} \mathrm{C}\right)$ for an hour 
and then freeze dried (Christ Gamma 2-16, Martin Christ Gefriertrocknungsanlagen, Germany) until constant weight was achieved. The dried samples were finely ground in a mill (Apex Comminuting Mill, Sherborne, Dorset, UK), sieved through a 150 mesh screen (particle size $<0.1 \mathrm{~mm})$, thoroughly mixed and stored in the freezer $\left(-80^{\circ} \mathrm{C}\right)$ until further analysis.

\subsection{Enzyme activity test}

Enzyme activity assays were performed at $45^{\circ} \mathrm{C}$ in sodium phosphate buffer at $\mathrm{pH}$ 4.5. One unit of enzyme was defined as the amount of enzyme used to release $1 \mu \mathrm{mol}$ of product per minute. FAE was assayed with methyl ferulate as the substrate as previously described by Kroon, Williamson (32). The amount of FA that was released was analysed by using HPLC as describe in Section 2.6. The activity of Trichorderma viride xylanase was assayed using beech wood arabinoxylan $(1 \mathrm{mg} / \mathrm{mL})$ as the substrate. Xylanase activity was determined by measuring the release of reducing sugar by 3,5-Dinitrosalicylic acid (DNS) reagent (ㅍ3), and was expressed as xylose equivalent. Briefly, $4 \mathrm{~mL}$ of DNS reagent was added to $1 \mathrm{~mL}$ of test sample and placed in boiling water for 5 minutes. The reaction was terminated by placing tubes in a boiling water bath for 10 minutes and the absorbance was read at 540nm.

\subsection{Preliminary work: determination of independent variables and their levels}

Preliminary experiments were conducted to select a suitable range of enzyme concentration, temperature, $\mathrm{pH}$ and time of FAE and $\mathrm{XY}$ for the design of the experimental RSM run. First, the concentration of FAE was determined by hydrolysing freeze dried SCC (5\%) using various concentrations of FAE $\left(0.02,0.05,0.19 \mathrm{U} / \mathrm{g}\right.$ of SCC) for 4 hours at $37^{\circ} \mathrm{C}$ and $\mathrm{pH} 6.5$ (optimum temperature and $\mathrm{pH}$ from manufacturer). FAE concentration at $0.02 \mathrm{U} / \mathrm{g}$ 
of SCC showed the highest amount of FA (Supplementary material, Figure S1). Then, hydrolysis of FA from freeze dried SCC (0.1g) using FAE (0.02U/g) was carried out at different $\mathrm{pH}(\mathrm{pH} 4,5,6,7)$ and temperature $\left(20,35,40,50,60^{\circ} \mathrm{C}\right)$ for an hour to obtain the optimum $\mathrm{pH}$ and temperature of FAE. The concentration of enzyme used in this research is lower than the amount reported by Pérez-Rodríguez, Torrado Agrasar (26) (0.044U of FAE per gram of dry

milled corn cob). The content of FA was then quantified using HPLC (Section 2.6). Similarly, the end product of XY hydrolysis (878.9 U/g of SCC) at different pH and temperature, xylose, was analysed using the DNS method as describe in Section 2.3.

Adopting the best working temperature $\left(55^{\circ} \mathrm{C}\right)$ and $\mathrm{pH}(5.5)$ for both $\mathrm{FAE}$ and $\mathrm{XY}$, the combination of FAE:XY at different ratios (1:0, 1:1, 1:10, 1:100, 1:1000, 1:10000, 2:0, 2:1, 2:10, 2:100, 2:1000 and 2:10000 U/U) were used to determine the best concentration for the maximum release of FA from SCC. The combination of FAE:XY at 1:10000 was found to release the maximum amount of FA (Supplementary material, Figure S2). Finally, FAE at $0.02 \mathrm{U} / \mathrm{g}$ with $\mathrm{XY}$ at $(9048.5 \mathrm{U} / \mathrm{g})$ was used to hydrolyse $0.1 \mathrm{~g}$ of SCC at $55^{\circ} \mathrm{C}$ and $\mathrm{pH} 5.5$ at various extraction time ( 1 to 24 hours) to determine the best extraction time for the release of FA from SCC. Based on the results, the three levels (lower, middle, upper) of each variable were determined and selected for RSM. All experiments were carried out in duplicate $(n=2)$ unless otherwise mentioned.

\subsection{Enzymatic hydrolysis}

Five grams of freeze dried SCC powder were defatted in a Soxhlet apparatus with hexane for six hours before the hydrolysis. For each experiment, a mixture of defatted SCC (0.1g) with 
varying amount of phosphate citrate buffer, FAE (0.00 to $0.04 \mathrm{U} / \mathrm{g})$ and $\mathrm{XY}$ enzymes $(0.00$ to 18093.50 U/g) was used as shown in Table 1. The mixtures were stirred in a shaking water bath at different reaction temperatures $\left(45\right.$ to $\left.65^{\circ} \mathrm{C}\right)$, for three hours. The $\mathrm{pH}$ of the mixtures was varied from $\mathrm{pH} 4.5$ to 6.5 . The range of enzymes, $\mathrm{pH}$ and incubation temperature were determined based on the preliminary experiments. After the reaction was completed, the enzyme was inactivated by placing the mixture in a water bath at $90^{\circ} \mathrm{C}$ for five minutes. The suspension was centrifuged at 18,000 xg for ten minutes and the supernatant was collected. FA in the supernatant was extracted 6 times using diethyl ether at a supernatant-to-solvent ratio of 1:1 and was evaporated to dryness. The extract containing the FA was then re-dissolved in methanol prior to HPLC analysis.

\subsection{HPLC analysis of FA}

The quantification of FA was carried out according to the method as described in Lau, Harbourne (13). Briefly, the analysis was performed with HP Agilent 1050 liquid chromatography equipped with a DAD detector, with a Zorbax SB-C18 column (2.1 x 15mm, 1.8 micron). The mobile phase used was (A) formic acid/HPLC water $(0.1: 100 \mathrm{v} / \mathrm{v})$ and (B) formic acid/acetonitrile (0.1/100 v/v). Solvent B was increased to 25\% (0- $25 \mathrm{~min})$, followed by $90 \%$ B for 30 minutes and then a final wash of $100 \%$ B for 10 minutes. The injection volume was $5 \mu \mathrm{L}$ with a flow rate of $0.2 \mathrm{~mL} / \mathrm{min}$. Detection at $280 \mathrm{~nm}$ was used for the quantification of FA using an external calibration curve (concentration from 0.01 to $0.2 \mathrm{~g} \mathrm{~kg}^{-1}$ of FA; $\mathrm{R}_{2}=$ 0.9998).

\subsection{Experimental design}


RSM was used to determine the optimum conditions for the enzymatic hydrolysis of FA from SCC powder. After determining the preliminary range of the extraction variables, a five-levelfour-factor central composite rotatable design (CCRD) with 31 experiments was employed in this study (Table 1). The experimental design and statistical analysis were performed using Minitab $^{\circledR}$ software 17.1.0. The variables optimised were concentration of FAE $\left(X_{1}\right)$, concentration of $\mathrm{XY}\left(X_{2}\right), \mathrm{pH}\left(X_{3}\right)$ and temperature $\left(X_{4}\right)$. The design consisted of sixteen factorial points, eight axial points and seven replicates of the centre point. The 31 experiments were randomised and the response (yield of FA) was recorded in Table 2. Data from the CCRD were analysed by multiple regression to fit the quadratic polynomial model. The analysis of variance and the effect and regression coefficients of individual linear, quadratic and interaction terms were determined. $p$-values of less than 0.05 were considered to be statistically significant.

Verification and validation of the model were conducted by running three additional confirmation experiments using the optimum conditions generated by the RSM. The experimental and predicted values were compared and tested for statistical differences.

\subsection{RESULTS AND DISCUSSION}

\subsection{Preliminary determination of temperature, $\mathrm{pH}, \mathrm{FAE}$ and $\mathrm{XY}$ ranges in RSM}

The efficiency of FAE and XY is indicated by the increasing yield of FA and xylose, respectively. For FAE, the extraction yield of FA increased with the increase in $\mathrm{pH}$ value $(\mathrm{pH}$ 4 to $\mathrm{pH} 6.5)$ and reached a maximum concentration (0.28 $\pm 0.00 \mathrm{mg} \mathrm{FA} / \mathrm{g})$ at $\mathrm{pH} 6$ (Figure $1 \mathrm{~A})$. Furthermore the amount of FA extracted by FAE increased as extraction temperature increased 
from 20 to $50^{\circ} \mathrm{C}$ (Figure 1B), reaching the maximum yield $(0.20 \pm 0.03 \mathrm{mg} \mathrm{FA} / \mathrm{g})$ at $50^{\circ} \mathrm{C}$. Previously, Topakas, Vafiadi (34) reported that microbial FAEs have a wide range of temperature and $\mathrm{pH}$ dependences, with optimal activities occurring between 30 to $60^{\circ} \mathrm{C}$ and $\mathrm{pH}$ 4-8 . Therefore, the FAE used in this experiment was working within its optimal temperature and $\mathrm{pH}$ range.

The yield of xylose by $\mathrm{XY}$ increased as the $\mathrm{pH}$ increased from $\mathrm{pH} 3$ to $\mathrm{pH} 5$, and decreased as the $\mathrm{pH}$ increased further to $\mathrm{pH} 7.5$ (Figure 1A). In addition, the yield of xylose increased as temperature increased from $20^{\circ} \mathrm{C}$ to $60^{\circ} \mathrm{C}$, with a maximum yield of $13.61 \pm$ 0.13mg XE/g (Figure 1B). The yield of xylose decreased rapidly as temperature increased to $70^{\circ} \mathrm{C}$. Results from this research are in agreement with Polizeli, Rizzatti (35), where they reported that the peak activity of endoxylanases generally falls between 40 and $80^{\circ} \mathrm{C}$ and between $\mathrm{pH} 4.0$ and 6.5. Iyer and Ananthanarayan (36) reported that several phenomenon are known to promote changes of the activity and spatial configuration of an enzyme such as $\mathrm{pH}$, ionic strength, temperature, autolysis or chemical agents. They further reported that these physical denaturants can disrupt the hydrogen bond in the enzyme and results in aggregation or formation of highly disordered structure. Therefore, it was crucial to determine the best working $\mathrm{pH}$ and temperature for both FAE and $\mathrm{XY}$ used in the experiment.

Figure 1C shows that the yield of FA was markedly affected during the first 6 hours of hydrolysis. An increase in incubation time for up to 24 hours did not increase the yield of FA. No significant difference was found between 3 hours $(1.05 \pm 0.00 \mathrm{mg}$ FA/g) and 6 hours $(1.02$ $\pm 0.03 \mathrm{mg} \mathrm{FA} / \mathrm{g}$ ) of extraction, which might be due to the accumulation of products inhibiting enzyme activity or the depletion of the substrates. In a study conducted by Frieden and Walter 
(37) on product inhibition of enzyme, it was reported that the products of almost all enzymecatalysed reactions may act as suppressants when present in high enough concentrations relative to the enzyme and substrate. Consequently, a period of 3 hours was chosen and used throughout the experiments.

Therefore, when taking into consideration the best working temperature and $\mathrm{pH}$ conditions for both FAE and $\mathrm{XY}, 55^{\circ} \mathrm{C}$ and $\mathrm{pH} 5.5$ were chosen as the middle point for RSM, along with $50^{\circ} \mathrm{C}$ and $\mathrm{pH} 5$ for the lower point, and $60^{\circ} \mathrm{C}$ and $\mathrm{pH} 5$ for the high point (Table 1).

\subsection{Statistical Analysis and the model fitting}

In this study, there were a total of 31 runs for optimizing the four individual parameters in the CCRD. The yield of FA along with the experimental conditions are shown in Table 2. Results showed that the yield of FA ranged from 0.00 to $1.45 \mathrm{~g} \mathrm{~kg}^{-1} \mathrm{FA}$. The maximum amount of FA $\left(1.45 \mathrm{~g} \mathrm{~kg}^{-1}\right)$ was found in conditions of $X_{1}=0.0285 \mathrm{U} / \mathrm{g}, X_{2}=4526 \mathrm{U} / \mathrm{g}, X_{3}=5, X_{4}=50^{\circ} \mathrm{C}$. The results were fitted with a second order polynomial equation:

mg FA $=3.53+65.1 X_{1}-0.0002 X_{2}+0.32 X_{3}-0.082 X_{4}-1838 X_{1}^{2}-0.00 X_{2}^{2}-0.0625 X_{3}^{2}$

$+0.000351 X_{4}^{2}-0.001 X_{1} X_{2}+3.34 X_{1} X_{3}+0.173 X_{1} X_{4}+0.000032 X_{2} X_{3}+0.000003 X_{2} X_{4}-$ $0.001 X_{3} X_{4}$

The statistical significance of the regression model was evaluated by the $p$-value and F-test, and the analysis of variance (ANOVA) for the response surface quadratic model is shown in Table 3 . The determination coefficient $\left(\mathrm{R}^{2}=0.893\right)$ indicates that the model was adequate for prediction within the range of experimental variables. Table 3 showed that the linear coefficient $\left(X_{1}\right)$ and the quadratic coefficient $\left(X_{1}^{2}\right.$ and $\left.X_{2}^{2}\right)$ were found significant at 
$p<0.001$. The linear coefficient $\left(X_{2}\right.$ and $\left.X_{4}\right)$ and interaction coefficient $\left(X_{2} X_{3}\right)$ were significant at $p<0.01$ and $p<0.05$. The other term coefficients $\left(X_{3}, X_{3}{ }^{2}, X_{4}{ }^{2}, X_{1} X_{3}, X_{1} X_{4}, X_{2} X_{4}\right.$ and $\left.X_{3} X_{4}\right)$ were not statistically significant $(p>0.05)$. Three-dimensional and contour plots were used to predict the relationships between the dependent and independent variables (Figure 2 and 3).

\subsection{Effect of FAE, XY, pH and temperature on the yield of FA}

The effect of FAE $\left(X_{1}\right)$ concentration, $\mathrm{XY}\left(X_{2}\right)$ concentration, $\mathrm{pH}\left(X_{3}\right)$, temperature $\left(X_{4}\right)$ and their interactions on the extraction efficiency of FA from SCC are reported in Table 3. The yield of FA was positively correlated to the linear effect of FAE concentration $(p \leq 0.001), X Y$ concentration $(\mathrm{p} \leq 0.01)$ and temperature $(\mathrm{p} \leq 0.01)$. Concentration of FAE was highly significant $(\mathrm{p}<0.001)$ in the release of FA from SCC. Similarly, concentration of XY $\left(X_{2}\right)$ was found to be significant in this study. The presence of $\mathrm{XY}$ was reported to contribute towards the degradation of arabinoxylan, and thus enhance the release of FA. These endoxylanases attack the arabinoxylan backbone in an irregular manner, causing a decrease in the degree of polymerisation of the substrate and thus liberating the xylose, xylobiose and oligomers while

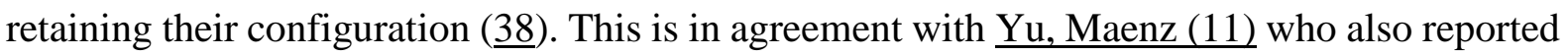
the release of FA from oat hulls using combinations of FAE and XY.

The effect of various parameters ( $\mathrm{pH}$, temperature and concentration of FAE and XY) and their interaction on the yield of FA is illustrated in the response surface plot. To visualise the effect of independent parameters and their interaction, three dimensional (Figure 2) and contour plot (Figure 3) were used to show the effects of two factors on the response at a time while keeping the other two factors at level zero. The three dimensional and contour plots in 
Figure 2 and 3a, which show the yield of FA as a function of FAE and XY concentration at a fixed extraction $\mathrm{pH}(\mathrm{pH} 5.5)$ and temperature $\left(50^{\circ} \mathrm{C}\right)$, indicated that the extraction yield of $\mathrm{FA}$ increased as the concentration of FAE increased from 0.00 to $0.03 \mathrm{U} / \mathrm{g}$, followed by a decrease in the extraction yield of FA at FAE concentrations higher than 0.03U/g. Similarly, the yield of FA increased as the concentration of $\mathrm{XY}$ increased to $11,000 \mathrm{U} / \mathrm{g}$, and decreased as concentration of XY increased.

The three dimensional response and the contour plots at varying FAE concentration over a range of $\mathrm{pH}$ at fixed $\mathrm{XY}$ concentration and temperature are presented in Figure 2 and 3b. It can be observed that the yield of FA increased as FAE increased to $0.08 \mathrm{U} / \mathrm{g}$, however, as pH increased from pH 6.0 to 6.5, the yield of FA decreased. In Figure 2 and 3c, the three dimensional response surface and the contour plots were developed for the extraction yield of FA with varying $\mathrm{pH}$ and $\mathrm{XY}$ concentration at a fixed FAE concentration and temperature. The plots indicated that the maximum extraction yield of FA can be achieved when the concentration of XY increased to 10,000U, and decreased at higher concentration of XY. It also showed that yield of FA decreased as $\mathrm{pH}$ increased from $\mathrm{pH} 6.0$ to 6.5.

Figure 2 and 3d showed the three dimensional response surface plot and contour plot at varying temperature and FAE concentration at fixed extraction conditions of $\mathrm{pH} 5.5$ and $\mathrm{XY}$ concentration. It can be seen that increasing FAE concentration increases the yield of FA, however, as temperature increases, the yield of FA decreases. It can be observed that the yield of FA by XY decreases as temperature increases above $45^{\circ} \mathrm{C}$ (Figure 2 and 3e). However, no interactions were found between temperature and $\mathrm{pH}$ at fixed amount of FAE and $\mathrm{XY}$ concentration (Figure 2 and 3f). 


\subsection{Verification of predictive model}

The accuracy of the model equation for predicting the optimum response value was carried out under the following condition: FAE concentration $(0.02 \mathrm{U} / \mathrm{g}), \mathrm{XY}$ concentration (3472 U/g), $\mathrm{pH}(4.5)$ and temperature $\left(45^{\circ} \mathrm{C}\right)$. This set of optimum conditions was determined by the RSM optimization (Table 4) and was used to validate the experimental and predicted yields of the responses using the model equation. A mean value of $1.69 \pm 0.02 \mathrm{~g} \mathrm{~kg}^{-1}(\mathrm{n}=3)$ was obtained from the experiment. This further validates the RSM model, showing that the model was adequate for the optimization of FA extraction from SCC.

Pérez-Rodríguez, Torrado Agrasar (26) reported that the enzymatic hydrolysis of corn cob using Ultraflo ${ }^{\circledR}$, in combination with thermal pre-treatment released a higher amount of FA (226mg/L) than the raw sample $(177 \mathrm{mg} / \mathrm{L})$. As compared to the FA content obtained by alkali hydrolysis (3.06g kg-1 of SCC, Chapter 2), enzymatic hydrolysis only extracted about half of the amount of FA in SCC (1.69g kg-1 of SCC). This result was lower than oat hull (69\%) (11) and wheat bran (95\%) (27) but higher than that from maize bran (0.6\%) (모) and barley spent grain (30\%) (40). The discrepancy in the release of FA might be due to the complexity of the cell wall material (lignification), and also the physical and steric factors caused by branching of the arabinoxylan backbone (11). Faulds, Kroon (39) reported that the highly branched xylose in the side chain of heteroxylan backbone of maize bran may hinder the action of endoxylanases, thus FAE can only act on those easily accessible regions. Therefore, lesssubstituted xylan substrate such as barley spent grain and wheat bran are better substrates for

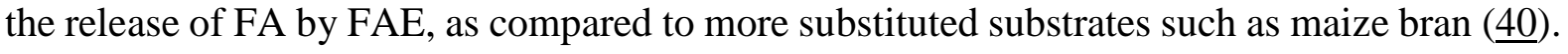
Furthermore, wheat bran containing nonlignified cell walls is more susceptible to enzymatic 


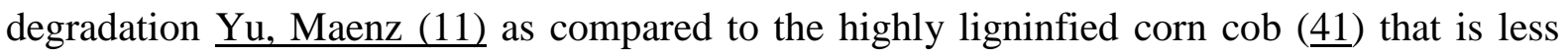
susceptible to the esterase.

\subsection{CONCLUSION}

RSM is a useful tool in the optimization of the enzymatic hydrolysis of FA from sweet corn cob. The concentration of FAE, XY and temperature markedly affects the extraction efficiency of FA from sweet corn cob and thus, optimization of these parameters is crucial to obtain the maximum yield of FA. Under the optimum condition, the yield of FA $(1.69 \pm 0.02 \mathrm{~g}$ $\mathrm{kg}^{-1}$ ) agreed closely with the predicted yield obtained from the model. Enzymatic hydrolysis offers several advantages including less time required ( 3 hours as compared to 6 hours in alkali hydrolysis), no need for a chemical solvent and is product specific. However, enzymatic hydrolysis of SCC with the combination of FAE and XY does not release a high amount of FA as compared to alkali hydrolysis. Therefore, combination of novel technologies with enzymatic hydrolysis may be further explored to increase the yield of extraction for FA in SCC.

\subsection{Acknowledgement}

The authors are particularly grateful to Barfoots of Botley Company Ltd for the supply of sweet corn cob.

\subsection{Conflict of Interest}

The authors declared that they have no conflict of interest.

This research did not receive any specific grant from funding agencies in the public, commercial, or not-for-profit sectors. 


\section{References}

1. Kim S, Dale BE. Global potential bioethanol production from wasted crops and crop residues. Biomass and Bioenergy. 2004;26(4):361-75.

2. Salleh NHM, Daud MZM, Arbain D, Ahmad MS, Ismail KSK. Optimization of alkaline hydrolysis of paddy straw for ferulic acid extraction. Industrial Crops and Products. 2011;34(3):1635-40.

3. Zheng J, Choo K, Bradt C, Lehoux R, Rehmann L. Enzymatic hydrolysis of steam exploded corncob residues after pretreatment in a twin-screw extruder. Biotechnology Reports. 2014;3:99-107.

4. Leys LJ, McGaraughty S, Radek RJ. Rat housed on corn cob bedding show less slowwave sleep. Journal of the American Association for Laboratory Animal Science. 2012;51(6):764-8.

5. Sánchez C, Serrano L, Andres MA, Labidi J. Furfural production from corn cobs autohydrolysis liquors by microwave technology. Industrial Crops and Products. 2013;42:5139.

6. Tsai WT, Chang CY, Wang SY, Chang CF, Chien SF, Sun HF. Cleaner production of carbon adsorbents by utilizing agricultural waste corn cob. Resources, Conservation and Recycling. 2001;32(1):43-53.

7. Perotti NI, Molina OE. Corn cob as a bacterial substrate for the production of forage protein. Biological Wastes. 1988;26(2):125-31.

8. Kumar N, Pruthi V. Potential applications of ferulic acid from natural sources. Biotechnology Reports. 2014;4:86-93. 
9. Srinivasan M, Sudheer AR, Menon VP. Ferulic Acid: Therapeutic Potential Through Its Antioxidant Property. Journal of Clinical Biochemistry and Nutrition. 2007;40(2):92-100.

10. Graf E. Antioxidant potential of ferulic acid. Free Radical Biology and Medicine. 1992;13(4):435-48.

11. Yu P, Maenz DD, McKinnon JJ, Racz VJ, Christensen DA. Release of Ferulic Acid from Oat Hulls by Aspergillus Ferulic Acid Esterase and Trichoderma Xylanase. Journal of Agricultural and Food Chemistry. 2002;50(6):1625-30.

12. Buranov AU, Mazza G. Extraction and purification of ferulic acid from flax shives, wheat and corn bran by alkaline hydrolysis and pressurised solvents. Food Chemistry. 2009;115(4):1542-8.

13. Lau T, Harbourne N, Oruña-Concha MJ. Valorisation of sweet corn (Zea mays) cob by extraction of valuable compounds. International Journal of Food Science \& Technology. 2019;54(4):1240-6.

14. Xu F, Sun R, Sun J, Liu C, He B, Fan J. Determination of cell wall ferulic and pcoumaric acids in sugarcane bagasse. Analytica Chimica Acta. 2005;552(1):207-17.

15. Li P, Li SP, Lao SC, Fu CM, Kan KKW, Wang YT. Optimization of pressurized liquid extraction for Z-ligustilide, Z-butylidenephthalide and ferulic acid in Angelica sinensis. Journal of Pharmaceutical and Biomedical Analysis. 2006;40(5):1073-9.

16. Sun Y, Wang W. Ultrasonic extraction of ferulic acid from Ligusticum chuanxiong. Journal of the Chinese Institute of Chemical Engineers. 2008;39(6):653-6.

17. Sun Y, Li S, Song H, Tian S. Extraction of ferulic acid from Angelica sinensis with supercritical CO2. Natural Product Research. 2006;20(9):835-41. 
18. Liu Z, Wang J, Shen P, Wang C, Shen Y. Microwave-assisted extraction and highspeed counter-current chromatography purification of ferulic acid from Radix Angelicae sinensis. Separation and Purification Technology. 2006;52(1):18-21.

19. Mussatto SI, Dragone G, Roberto IC. Ferulic and p-coumaric acids extraction by alkaline hydrolysis of brewer's spent grain. Industrial Crops and Products. 2007;25(2):231-7. 20. Torre P, Aliakbarian B, Rivas B, Domínguez JM, Converti A. Release of ferulic acid from corn cobs by alkaline hydrolysis. Biochemical Engineering Journal. 2008;40(3):500-6.

21. Ares P, Garrote, Domínguez, Parajó. Phenolics production from alkaline hydrolysis of autohydrolysis liquors. CyTA - Journal of Food. 2016;14(2):255-65.

22. Lau T, Harbourne N, Oruña-Concha MJ. Valorisation of sweet corn (Zea mays) cob by extraction of valuable compounds. International Journal of Food Science \& Technology. 2019;54(0):1240-6.

23. Ares-Peón AJ, Garrote G, Domínguez H, Parajó JC. Phenolics production from alkaline hydrolysis of autohydrolysis liquors. CyTA - Journal of Food. 2016;14(2):255-65.

24. Alinia R, Zabihi S, Esmaeilzadeh F, Kalajahi JF. Pretreatment of wheat straw by supercritical $\mathrm{CO}_{2}$ and its enzymatic hydrolysis for sugar production. Biosystems Engineering. 2010;107(1):61-6.

25. Alvira P, Tomás-Pejó E, Ballesteros M, Negro MJ. Pretreatment technologies for an efficient bioethanol production process based on enzymatic hydrolysis: A review. Bioresource Technology. 2010;101(13):4851-61. 
26. Pérez-Rodríguez N, Torrado Agrasar A, Domínguez JM. High hydrostatic pressure as pretreatment and adjuvant for the enzymatic release of ferulic acid from corn cob. Process Biochemistry. 2017;58:204-10.

27. Faulds CB, Williamson G. Release of ferulic acid from wheat bran by a ferulic acid esterase (FAE-III) from Aspergillus niger. Applied Microbiology and Biotechnology. 1995;43:1082-7.

28. Yin X, You Q, Jiang Z. Optimization of enzyme assisted extraction of polysaccharides from Tricholoma matsutake by response surface methodology. Carbohydrate Polymers. 2011;86(3):1358-64.

29. Tanyildizi MS, Ozer D, Ellibol M. Optimization of a-amylase production by Bacillus sp. using response surface methodology. Process Biochemistry 2005;40:2291-6.

30. Bezerra MA, Santelli RE, Oliveira EP, Villar LS, Escaleira LA. Response surface methodology (RSM) as a tool for optimization in analytical chemistry. Talanta. 2008;76(5):965-77.

31. Tilay A, Bule M, Kishenkumar J, Annapure U. Preparation of Ferulic Acid from Agricultural Wastes: Its Improved Extraction and Purification. Journal of Agricultural and Food Chemistry. 2008;56(17):7644-8.

32. Kroon PA, Williamson G, Fish NM, Archer DB, Belshaw NJ. A modular esterase from Penicillium funiculosum which releases ferulic acid from plant cell walls and binds crystalline cellulose contains a carbohydrate binding module Modular cinnamoyl esterase from P.funiculosum. European Journal of Biochemistry 2000;267:6740-52. 
33. Saqib AAN, Whitney PJ. Differential behaviour of the dinitrosalicylic acid (DNS) reagent towards mono- and di-saccharide sugars. Biomass and Bioenergy. 2011;35(11):474850.

34. Topakas E, Vafiadi C, Christakopoulos P. Microbial production, characterization and applications of feruloyl esterases. Process Biochemistry. 2007;42(4):497-509.

35. Polizeli MLTM, Rizzatti ACS, Monti R, Terenzi HF, Jorge JS, Amorim DS. Xylanases from fungi: properties and industrial applications. Applied Microbiology and Biotechnology. 2005;67(5):577-91.

36. Iyer PV, Ananthanarayan L. Enzyme stability and stabilization—Aqueous and nonaqueous environment. Process Biochemistry. 2008;43(10):1019-32.

37. Frieden E, Walter C. Prevalence and Significance of the Product Inhibition of Enzymes. Nature. 1963;198:834.

38. Courtin CM, Delcour JA. Arabinoxylans and Endoxylanases in Wheat Flour Breadmaking. Journal of Cereal Science. 2002;35(3):225-43.

39. Faulds CB, Kroon PA, Saulnier L, Thibault J-F, Williamson G. Release of ferulic acid from maize bran and derived oligosaccharides by Aspergillus niger esterases. Carbohydrate Polymers. 1995;27(3):187-90.

40. Bartolome B, Gomez-Cordoves C. Barley spent grain: release of hydroxycinnamic acids (ferulic and p-coumaric acid) by commercial enzyme preparations. Journal of the Science of Food and Agriculture. 1999;79:435-9. 
41. Pastell H, Virkki L, Harju E, Tuomainen P, Tenkanen M. Presence of $1 \rightarrow$ 3-linked 2O- $\beta$-d-xylopyranosyl- $\alpha$-l-arabinofuranosyl side chains in cereal arabinoxylans. Carbohydrate Research. 2009;344(18):2480-8. 


\section{Figure Caption}

Figure 1: Effect of $\mathrm{pH}$, temperature and time on enzymatic hydrolysis of ferulic acid (FA) from sweet corn cob using ferulic acid esterase (FAE) and xylanase (XY). Different letters showed significant difference $(\mathrm{p}<0.05)$ between treatments.

Figure 2: Response surface (3-D) showing the effect of FAE $\left(X_{1}\right)$, XY concentration $\left(X_{2}\right)$, pH $\left(X_{3}\right)$ and temperature $\left(X_{4}\right)$ on yield of ferulic acid (FA).

Figure 3: Contour plots showing the effect of FAE $\left(X_{1}\right), \mathrm{XY}$ concentration $\left(X_{2}\right), \mathrm{pH}\left(X_{3}\right)$ and temperature $\left(X_{4}\right)$ on yield of ferulic acid(FA). 

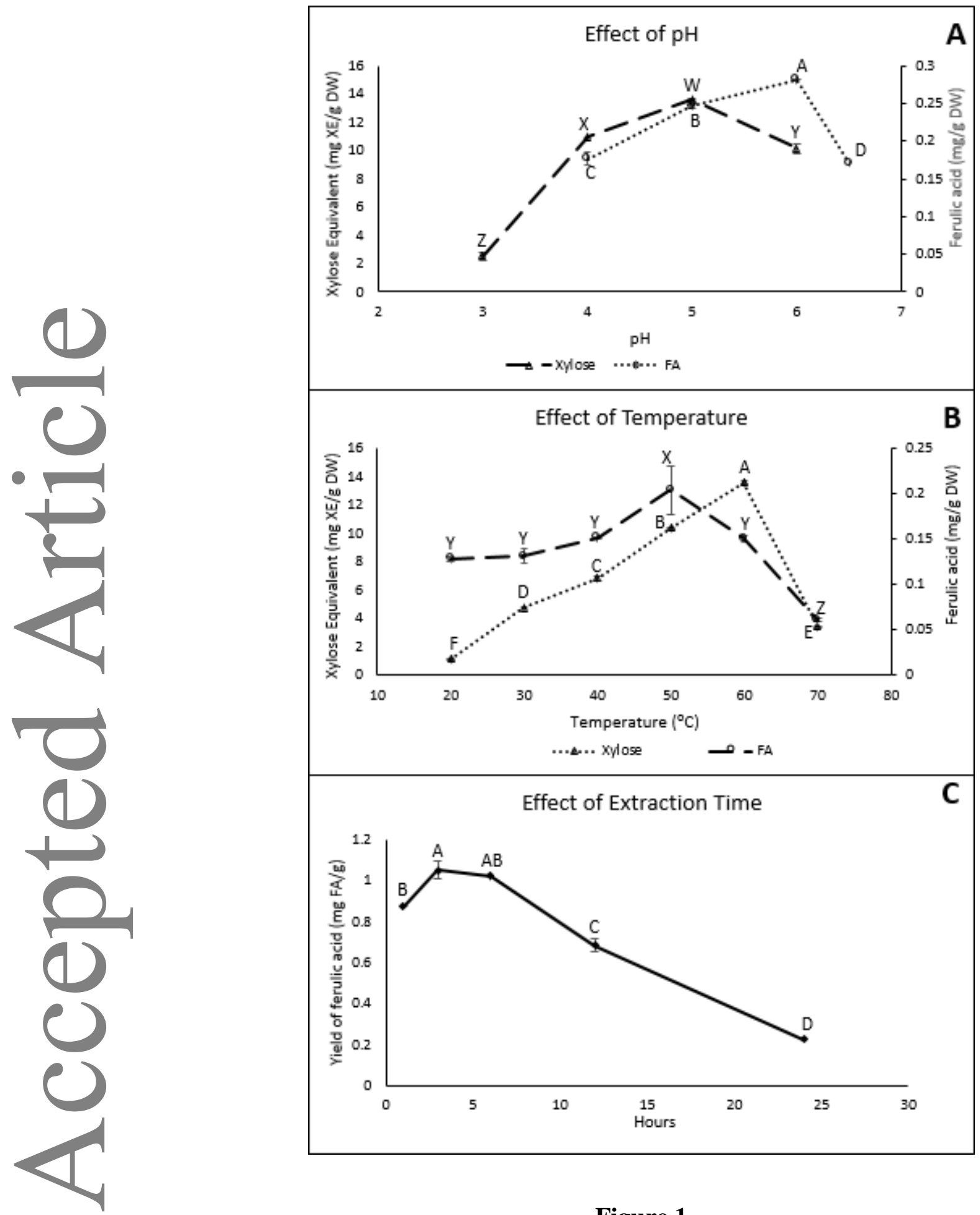

Figure 1 


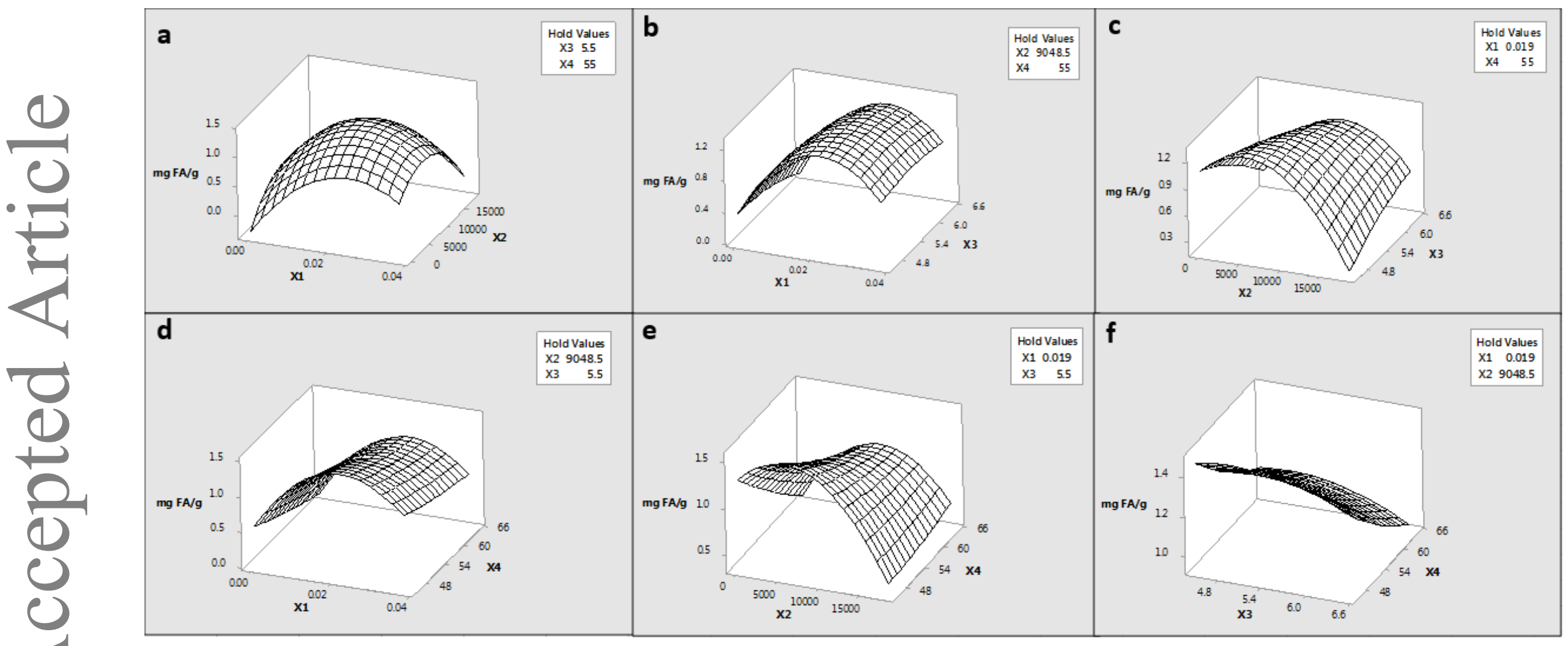

Figure 2 

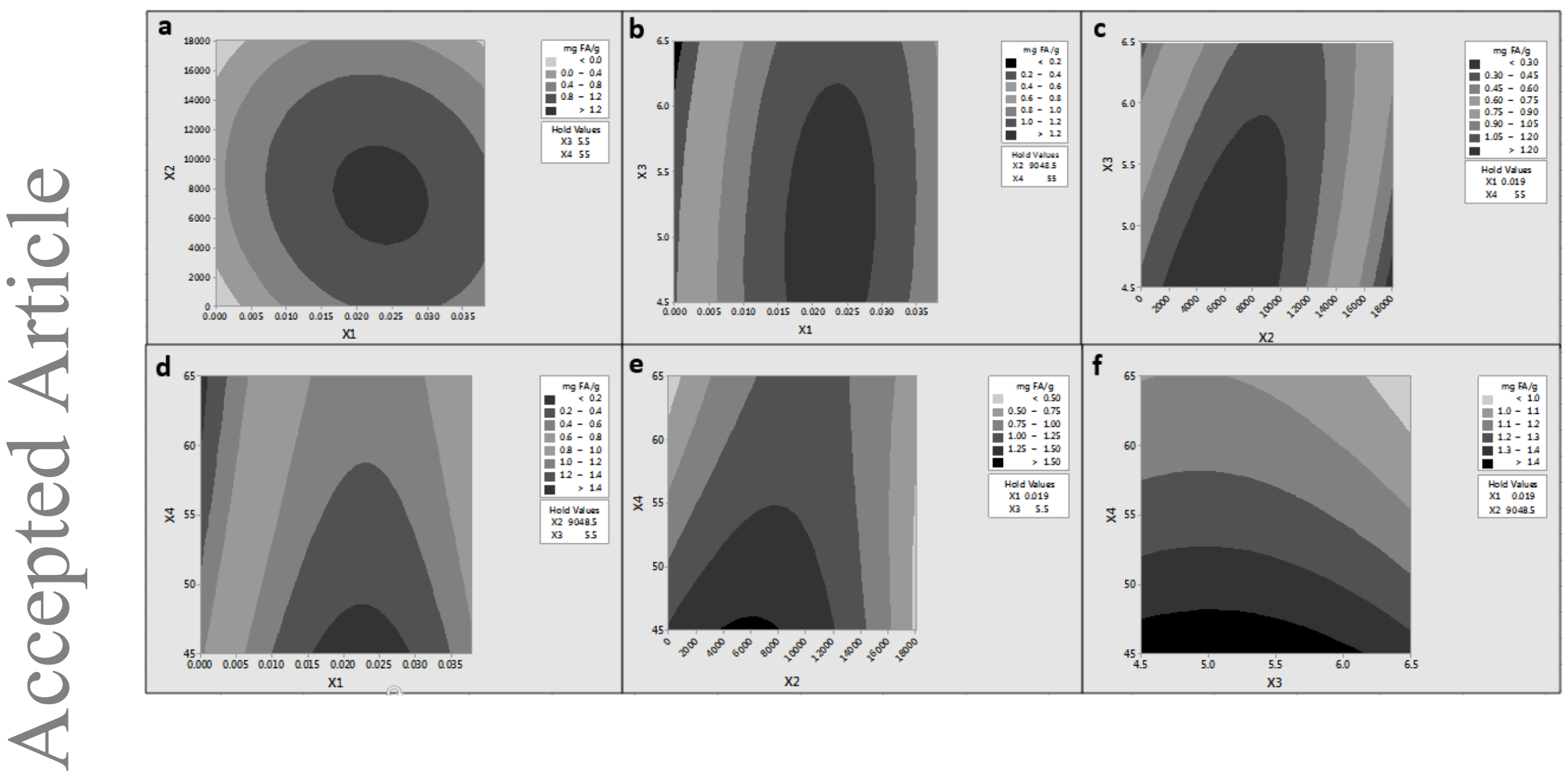

Figure 3 
Table 1: Variables and their levels for central composite rotatable design

\begin{tabular}{|l|c|c|c|c|c|}
\hline \multirow{2}{*}{ Variables } & \multicolumn{5}{c|}{ Levels } \\
\cline { 2 - 6 } & $-\boldsymbol{\alpha}$ & $\mathbf{- 1}$ & $\mathbf{0}$ & $\mathbf{+ 1}$ & $+\boldsymbol{\alpha}$ \\
\hline Ferulic acid esterase concentration/ $X_{1}$ & 0.00 & 0.01 & 0.02 & 0.03 & 0.04 \\
$(\mathrm{U} / \mathrm{g})$ & & & & & \\
\hline Xylanase concentration/ $X_{2}(\mathrm{U} / \mathrm{g})$ & 0.00 & 4526.00 & 9048.20 & 13571.00 & 18093.50 \\
\hline $\mathrm{pH} / X_{3}$ & 4.5 & 5.0 & 5.5 & 6.0 & 6.5 \\
\hline Temperature $/ X_{4}\left({ }^{\circ} \mathrm{C}\right)$ & & & & & 65 \\
\hline
\end{tabular}


Table 2: Central composite rotatable design and response values for the yield of ferulic acid ( $\left.\mathrm{g} \mathrm{kg}^{-1}\right)$

\begin{tabular}{|c|c|c|c|c|c|c|}
\hline \multirow{2}{*}{$\begin{array}{c}\text { Standard } \\
\text { Order }\end{array}$} & \multirow{2}{*}{$\begin{array}{c}\text { Concentration of } \\
\text { Ferulic acid esterase } / X_{1} \\
(U / g)\end{array}$} & \multirow{2}{*}{$\begin{array}{l}\text { Concentration of } \\
\text { Xylanase/ } \boldsymbol{X}_{2} \\
(\mathrm{U} / \mathrm{g})\end{array}$} & \multirow{2}{*}{$\begin{array}{c}\text { Extraction } \\
\qquad \mathrm{pH} / \boldsymbol{X}_{3}\end{array}$} & \multirow{2}{*}{$\begin{array}{c}\text { Extraction } \\
\text { Temperature } / X_{4} \\
\left({ }^{\circ} \mathrm{C}\right)\end{array}$} & \multicolumn{2}{|c|}{ Ferulic acid yield $\left(\mathrm{g} \mathrm{kg}^{-1}\right)$} \\
\hline & & & & & Experimental $^{\mathrm{a}}$ & Predicted \\
\hline 1 & 0.01 & 4526.00 & 5.00 & 50.00 & 1.20 & 1.14 \\
\hline 2 & 0.03 & 4526.00 & 5.00 & 50.00 & 1.45 & 1.42 \\
\hline 3 & 0.01 & 13571.00 & 5.00 & 50.00 & 0.85 & 0.78 \\
\hline 4 & 0.03 & 13571.00 & 5.00 & 50.00 & 0.84 & 0.92 \\
\hline 5 & 0.01 & 4526.00 & 6.00 & 50.00 & 1.02 & 0.94 \\
\hline 6 & 0.03 & 4526.00 & 6.00 & 50.00 & 1.23 & 1.28 \\
\hline 7 & 0.01 & 13571.00 & 6.00 & 50.00 & 0.85 & 0.83 \\
\hline 8 & 0.03 & 13571.00 & 6.00 & 50.00 & 0.98 & 1.02 \\
\hline
\end{tabular}




\begin{tabular}{|c|c|c|c|c|c|c|}
\hline 9 & 0.01 & 4526.00 & 5.00 & 60.00 & 0.91 & 0.83 \\
\hline 10 & 0.03 & 4526.00 & 5.00 & 60.00 & 1.11 & 1.15 \\
\hline 11 & 0.01 & 13571.00 & 5.00 & 60.00 & 0.73 & 0.73 \\
\hline 12 & 0.03 & 13571.00 & 5.00 & 60.00 & 0.81 & 0.90 \\
\hline 13 & 0.01 & 4526.00 & 6.00 & 60.00 & 0.62 & 0.57 \\
\hline 14 & 0.03 & 4526.00 & 6.00 & 60.00 & 0.93 & 0.95 \\
\hline 15 & 0.01 & 13571.00 & 6.00 & 60.00 & 0.79 & 0.73 \\
\hline 16 & 0.03 & 13571.00 & 6.00 & 60.00 & 0.91 & 0.95 \\
\hline 17 & 0.00 & 9048.50 & 5.50 & 55.00 & 0.00 & 0.46 \\
\hline 18 & 0.04 & 9048.50 & 5.50 & 55.00 & 1.00 & 0.97 \\
\hline 19 & 0.02 & 0.00 & 5.50 & 55.00 & 0.61 & 0.83 \\
\hline 20 & 0.02 & 18093.50 & 5.50 & 55.00 & 0.52 & 0.48 \\
\hline 21 & 0.02 & 9048.50 & 4.50 & 55.00 & 1.17 & 1.25 \\
\hline
\end{tabular}




\begin{tabular}{|c|c|c|c|c|c|c|}
\hline 22 & 0.02 & 9048.50 & 6.50 & 55.00 & 1.03 & 1.10 \\
\hline 23 & 0.02 & 9048.50 & 5.50 & 45.00 & 1.37 & 1.43 \\
\hline 24 & 0.02 & 9048.50 & 5.50 & 65.00 & 1.03 & 1.28 \\
\hline 25 & 0.02 & 9048.50 & 5.50 & 55.00 & 1.24 & 1.24 \\
\hline 26 & 0.02 & 9048.50 & 5.50 & 55.00 & 1.20 & 1.24 \\
\hline 27 & 0.02 & 9048.50 & 5.50 & 55.00 & 1.27 & 1.24 \\
\hline 28 & 0.02 & 9048.50 & 5.50 & 55.00 & 1.24 \\
\hline 30 & 0.02 & 9048.50 & 5.50 & 55.00 & 1.24 & 1.24 \\
\hline 31 & 0.02 & 9048.50 & 5.50 & 55.00 & 1.24 \\
\hline
\end{tabular}

${ }^{a}$ Averages of duplicated determination ( $\left.n=2\right)$ from experiments. 
Table 3: Estimated regression model of relationship between response variables (yield of ferulic acid) and independent variables ferulic acid esterase $\left(X_{1}\right)$, xylanase $\left(X_{2}\right)$, $\mathrm{pH}\left(X_{3}\right)$, and temperature $\left(X_{4}\right)$.

\begin{tabular}{|c|c|c|c|c|}
\hline Factor & Sum of Square & Mean Square & F-ratio & $p$-value \\
\hline$X_{1}$ & 0.45 & 0.45 & 25.36 & * \\
\hline$X_{1}^{2}$ & 0.79 & 0.79 & 44.17 & * \\
\hline$X_{2}$ & 0.15 & 0.15 & 8.37 & $* *$ \\
\hline$X_{2}^{2}$ & 0.64 & 0.64 & 35.83 & $*$ \\
\hline$X_{3}$ & 0.03 & 0.03 & 1.57 & NS \\
\hline$X_{3}^{2}$ & 0.01 & 0.01 & 0.39 & NS \\
\hline$X_{4}$ & 0.22 & 0.22 & 12.50 & $* *$ \\
\hline$X_{4}^{2}$ & 0.00 & 0.00 & 0.12 & NS \\
\hline$X_{1} X_{2}$ & 0.03 & 0.03 & 1.53 & NS \\
\hline$X_{1} X_{3}$ & 0.00 & 0.00 & 0.23 & NS \\
\hline$X_{1} X_{4}$ & 0.00 & 0.00 & 0.06 & NS \\
\hline$\overline{X_{2} X_{3}}$ & 0.08 & 0.08 & 4.65 & $* * *$ \\
\hline$\overline{X_{2} X_{4}}$ & 0.07 & 0.07 & 3.80 & NS \\
\hline$X_{3} X_{4}$ & 0.00 & 0.00 & 0.01 & NS \\
\hline
\end{tabular}

${ }^{*}$ Significance at $\mathrm{p} \leq 0.001$

${ }^{* *}$ Significance at $\mathrm{p} \leq 0.01$ 
${ }^{* * *}$ Significance at $\mathrm{p} \leq 0.05$

NS = not significant

Table 4: Predicted and experimental values of the responses at optimum condition

\begin{tabular}{|l|c|c|c|c|c|}
\hline & $\begin{array}{c}\text { FAE } \\
\text { Concentration } \\
\mathbf{( U / g )}\end{array}$ & $\begin{array}{c}\mathbf{X Y} \\
\text { Concentration } \\
\mathbf{( U / g )}\end{array}$ & $\mathbf{p H}$ & $\begin{array}{c}\text { Temperature } \\
\left({ }^{\mathbf{0}} \mathbf{C}\right)\end{array}$ & $\begin{array}{c}\text { Yield of } \\
\text { ferulic acid } \\
\mathbf{g ~ k g}^{-1} \mathbf{)}\end{array}$ \\
\hline Predicted & 0.02 & 3475.32 & 4.50 & 45.00 & 1.70 \\
\hline Experimental $^{\mathrm{a}}$ & 0.02 & 3475.32 & 4.50 & 45.00 & $1.69 \pm 0.02$ \\
\hline
\end{tabular}

${ }^{a}$ Means \pm standard deviation of triplicate determinations $(n=3)$ from experiments. 